\title{
PENGARUH PEMBERIAN EKSTRAK DAUN JAMBLANG (Egenia cumini Merr.) TERHADAP PERTUMBUHAN Streptococcus pyogenes
}

\author{
The Effect Of Java Plum (Egenia cumini Merr.) Leaf Extract Towards The Growth Of Streptococcus \\ pyogenes
}

\section{Asmawati, Jumain*}

Jurusan Farmasi Politeknik Kesehatan Kemenkes Makassar

*Koresponden Email : jumainfarmasi@gmail.com

DOI: https://doi.org/10.32382/mf.v16i2.1663

\section{ABSTRACT}

The flavonoids content of the leaf of Jamblang or Java plum (Egenia cumini Merr.) have the potential to be developed as an anti-microbial agents, especially for Streptococcus pyogenes infections. This research aims to determine the antibacterial activity of Java plum leaf extract (Egenia cumini Merr.) against the growth of Streptococcus pyogenes bacteria. The java plum leaf obtained in the Tamalanrea area of Makassar City was extracted using $96 \%$ ethanol by maceration. The dry extract obtained was prepared with concentrations of $2 \%, 4 \%$ and $8 \% \mathrm{w} / \mathrm{v}$ respectively and then tested for anti-bacteria by the agar diffusion method using Nutrient Agar media with a tetracycline comparison. The results showed that the inhibition zone diameter in Java plum Leaf Extract (Egenia cumini Merr.) at a concentration of $2 \% \mathrm{w} / \mathrm{v}$ was $29.0 \mathrm{~mm}, 4 \% \mathrm{w} / \mathrm{v}$ was $35.0 \mathrm{~mm}$, and $8 \% \mathrm{w} / \mathrm{v}$ was $42.0 \mathrm{~mm}$ as well as with Tetracyclines was 78, $\mathrm{mm}$. Therefore, it was concluded that Java plum Leaf Extract (Egenia cumini Merr.) at a concentration of 8\% $w / v$ has the greatest antibacterial power $(p<0.05)$, but the effect was smaller compared to Tetracycline $(p$ $<0.05)$.

Keywords Anti-Bacteria, Extract, Java Plum Leaf, Streptococcus pyogenes

\begin{abstract}
ABSTRAK
Kandungan Flavonoid dalam Daun Jamblang (Egenia cumini Merr.) berpotensi dikembangkan sebagai anti mikroba terutama pada infeksi Streptococcus pyogenes. Penelitian ini bertujuan untuk mengetahui aktivitas antibakteri ekstrak daun jamblang (Egenia cumini Merr.) terhadap pertumbuhan bakteri Streptococcus pyogenes. Daun jamblang Diperoleh di daerah Tamalanrea Kota Makassar, dibuat Ekstrak Menggunakan Etanol 96\% secara Maserasi. Ekstrak kering yang diperoleh dibuat Konsentrasi masing - masing 2\% b/v, $4 \% \mathrm{~b} / \mathrm{v}$ dan $8 \% \mathrm{~b} / \mathrm{v}$ lalu diuji anti bakterinya dengan metode Difusi Agar menggunakan Media Nutrient Agar dengan pembanding Tetrasiklin. Hasil penelitian menunjukkan diameter zona hambatan rata-rata pada Ekstrak Daun Jamlang (Egenia cumini Merr.) $2 \%$ b/v sebesar 29,0 mm, pada konsentrasi $4 \%$ b/v sebesar $35,0 \mathrm{~mm}$, dan pada konsentrasi $8 \%$ b/v sebesar 42,0 $\mathrm{mm}$ serta Tetrasiklin sebesar 78, mm, sehigga dapat disimpulkan Ekstrak Daun Jamblang (Egenia cumini Merr.) pada konsentrasi $8 \%$ b/v mempunyai daya antibakteri terbesar $(\mathrm{p}<0,05)$, namun efek tersebut masih lebih kecil bila dibandingkan dengan Tetrasiklin $(\mathrm{p}<0.05)$.
\end{abstract}

Kata Kunci Anti Bakteri, Ekstrak, Daun Jamblang, Streptococcus pyogenes

\section{PENDAHULUAN}

Setiap tahun jumlah masyarakat yang tinggal di daerah perkotaan terus meningkat, namun perkembangan jumlah penduduk di kota tidak sebanding dengan meningkatnya kualitas pelayanan kesehatan yang ada sehingga masalah-masalah kesehatan sering dialami oleh masyarakat perkotaan diantaranya penyakit infeksi. Fenomena urbanisasi atau perpindahan masyarakat dari daerah pedesaan ke kota yang menyebabkan meledaknya populasi penduduk dan tentunya berdampak pula pada kesehatan disertai polusi yang memperburuk kualitas udara di daerah perkotaan. Menurut data Badan Pusat statistik pada 2004, di Indonesia jumlah kendaraan bermotor setiap tahunnya bertambah $12 \%$ yang disertai dengan meningkatnya polutan berbahaya yang tiap hari terpaksa dihirup oleh warga seperti Karbon monoksida (CO), Hidrokarbon (HC), dan Nitrogen Oksida (NO) selain itu lebih dari 100 juta rakyat Indonesia masih sulit untuk mendapatkan akses air minum yang aman, sementara lebih dari $70 \%$ dari 220 juta penduduk Indonesia masih tergantung pada sumber air yang telah terkontaminasi 
Berbagai jenis penyakit baik itu menular maupun tidak menular, perubahan gaya hidup seperti kurang olah raga, mengkonsumsi makanan yang tidak bergizi dan merokok menyebabkan penyakit degeneratif semakin meningkat di masyarakat perkotaan, ironisnya penyebaran penyakit menular yang sudah ada sejak jaman dahulu seperti tuberkulosisi (TB), penyakit infeksi kulit lainnya, Diare dan demam berdarah belum dapat di tuntaskan penyebarannya. Salah satu infeksi kulit yang banyak timbul akibat urbanisasi adalah infeksi yang disebabkan Streptococcus pyogenes.

Streptococcus pyogenes merupakan bakteri gram positif, berbentuk bulat dan dapat tumbuh dalam rantai yang panjang. Streptococcus pyogenes dapat menyebabkan berbagai penyakit yang dikenal sebagai penyakit infeksi Streptococcus grup A yang terdiri dari infeksi kulit ringan hingga infeksi fasitis nekrosis yang dapat mengancam jiwa. (Ryan, 2014). Untuk mengatasi penyakit infeksi kulit ringan hingga sedang masyarakat daerah sering menggunakan tanaman obat tradisional diantaranya tumbuhan Jamblang (Eugenia cumini Merr)

Nama Jamblang (Eugenia cumini Merr) merupakan nama baru dari tanaman Syzygium cumini. ( Mahmoud 2001), Di negara lain seperti India dan Malaysia, tumbuhan ini dikenal dengan nama jaman, jambul, jambu, jamelong, dibeberapa daerah di Indonesia dikenal sebagai jambulan, jamblang (Jawa Barat), juwet atau duwet (Jawa Timur), dan jambu kaliang (Sumatra Barat) (Arifin, 2006). Hasil penelitian menunjukan Tumbuhan jamblang mengandung banyak senyawa kimia antara lain alkaloid, flavonoid, resin, tannin, dan minyak atsiri (Arifin, 2006). Flavonoid merupakan salah satu metabolit sekunder pada tumbuhan ini yang berfungsi mengobati banyak penyakit salah satunya sebagai anti mikroba, obat infeksi pada luka, anti jamur, anti virus, anti kanker, dan anti tumor. Selain itu flavonoid juga dapat digunakan sebagai anti bakteri, anti alergi, sitotoksik, dan anti hipertensi (Sriningsih, 2008). Walaupun penggunaan tumbuhan Jamblang (Eugenia cumini Merr) secara empiris digunakan oleh masyarakat, namun bukti efektifitas tanaman ini dalam menghambat atau membasmi bakteri Streptococcus pyogenes masih sangat kurang oleh karena itu penulis tertarik untuk mengetahui aktivitas antibakteri ekstrak daun jamblang terhadap pertumbuhan Bakteri Streptococcus pyogenes beserta Konsentrasi optimalnya.

\section{METODE}

Jenis dan Desain Penelitian
Penelitian ini bersifat eksplorisasi untuk mengetahui aktivitas antibakteri ekstrak daun jamblang terhadap pertumbuhan Bakteri Streptococcus pyogenes beserta konsentrasi optimalnya

\section{Waktu dan Tempat Penelitian}

Penelitian ini dilakukan pada bulan Februari hingga Agustus 2020 di Laboratorium Fitokimia dan Laboratorium Mikrobiologi Farmasi Jurusan Farmasi Poltekkes Makassar.

\section{Alat dan Bahan Yang Digunakan}

Alat-alat Yang Digunakan terdiri dari Autoklaf, Bunsen, Cawan petri, Erlemeyer, seperangkat alat Gelas, Inkubator, Kain flanel, Mistar geser, Ose bulat/lurus, Oven, Rotavapor, Spoit Labu alas bulat, dan Timbangan analitik.

Bahan Yang Digunakan terdiri Air suling, Air Steril, Aluminium Foil, biakan murni Streptococcus pyogenes, Daun Jamblang, Etanol 96\%, medium Nutrien Agar (NA), Paper disc, Tetrasiklin $\mathrm{HCl}$.

Prosedur Kerja

\section{Pengambilan Dan Pengolahan Bahan uji Pengambilan Bahan uji}

Bahan Uji yang digunakan adalah daun jamblang yang di ambil di Tamalanrea Kota Makassar dan dilakukan determinasi di Laboratorium Biologi Farmasi Poltekkes makassar.

\section{Pengelolahan Bahan Uji}

Bahan uji penelitian berupa Daun Jamblang yang telah dikumpulkan, dibersihkan kemudian dipotong-potong kecil dengan derajat halus $5 / 18$.

\section{Ekstraksi Bahan uji}

Bahan Uji Daun Jamblang yang telah dikeringkan kemudian, ditimbang 200 gram dan diekstraksi menggunakan metode maserasi dengan cara merendam sampel dengan etanol $96 \%$ sebanyak $2000 \mathrm{ml}$, kemudian tutup dan simpan selama 5 hari sambil sesekali diaduk selanjutnya disaring. Ampasnya dimasukan kembali ke dalam alat maserasi dan dilakukan seperti semula sampai cairan penyari tak berwarna atau di ulangi hingga 3 kali. Hasil ekstraksi dipekatkan dengan rotavapor kemudian diuapkan di atas penangas air hingga diperoleh ekstrak kental. Ekstrak kental diuapkan diatas penangas hingga di hasilkan eksrak kering.(Depkes, 1986)

\section{Pengujian Mikrobiologi}

\section{Sterilisasi Alat}


Semua alat yang di gunakan melalui tahap sterilisasi yang bertujuan untuk mematikan semua bentuk kehidupan mikroorganisme yang ada pada alat, khusus alat-alat dari gelas disterilkan dalam oven pada suhu $180^{\circ} \mathrm{C}$ selama 2 jam sedangkan alat Ose dan pinset disterilkan dengan cara pemijaran diatas api spirtus. Alat yang mempunyai ukuran atau berskala disterilkan pada autoktaf suhu $121^{\circ} \mathrm{C}$ selama 15 menit. (Depkes 1995)

\section{Pembuatan Media Nutrien Agar (NA)}

Ditimbang 2,5 gram Medium Nutrien Agar dan dimasukkan kedalam Erlenmeyer lalu dilarutkan dengan air suling sedikit demi sedikit dibantu dengan sedikit pemanasan agar semua bahan larut, diatur pada $\mathrm{pH}$ 7,0 dan dicukupkan volumenya dengan air suling $200 \mathrm{ml}$ disterilkan dalam autoklaf pada suhu $121^{\circ} \mathrm{C}$ selama 15 menit dengan tekanan 1 atmosfir.

\section{Penyiapan Bakteri Uji}

Bakteri yang digunakan adalah Streptococcus pyogenes, dari stok murni diambil 1 ose, lalu di inokulasi pada media Nutrien Agar miring, diinkubasi selama 24 jam pada suhu $37^{\circ} \mathrm{C}$. Biakan bakteri uji disuspensikan dengan larutan fisiologis $\mathrm{NaCl}$ 0,9\% steril.

\section{Penyiapan Sampel}

Sampel Ekstrak Daun Jamblang dibuat dengan variasi konsentrasi yaitu $2 \% \mathrm{~b} / \mathrm{v}, 4 \% \mathrm{~b} / \mathrm{v}$ dan $8 \% \mathrm{~b} / \mathrm{v}$ dengan cara ditimbang sebanyak 2 gram, disuspensikan dengan air suling steril hingga $100 \mathrm{ml}$ hingga diperoleh konsentrasi ekstrak $2 \% \mathrm{~b} / \mathrm{v}$, pembuatan ekstrak dengan konsentrasi $4 \%$ b/v, dan $8 \%$ b/v digunakan cara yang sama dengan menimbang ekstrak kering Daun jamblang sebanyak 4 gram, dan 8 gram.

\section{Pembuatan Pembanding Tetrasiklin HCl}

Ditimbang $50 \mathrm{mg}$ Tetrasiklin $\mathrm{HCl}$ dan dilarutkan dengan $100 \mathrm{ml}$ air suling steril (500 bpj) dari larutan stok 500 bpj kemudian Dipipet $2 \mathrm{ml}$ dicukupkan volumenya hingga $10 \mathrm{ml}$ (100 bpj) lalu dari larutan stok $100 \mathrm{bpj}$ dipipet $3 \mathrm{ml}$ larutan stok $100 \mathrm{bpj}$ dan dicukupkan volumenya hingga $10 \mathrm{ml}$ (30 bpj).

\section{Pengujian Sampel Terhadap Bakteri Uji.}

Media Nutrien Agar dituang secara aseptis kedalam masing-masing cawan petri sebanyak $15 \mathrm{ml}$ dibiarkan hingga memadat lalu diambil suspensi bakteri Streptococcus pyogenes dengan menggunakan swab steril, diinokulasikan secara merata pada medium dan dilanjutkan dengan meletakkan paperdisk yang telah direndam ekstrak Daun Jamblang konsentrasi $2 \% \mathrm{~b} / \mathrm{v}, 4 \% \mathrm{~b} / \mathrm{v}, 8 \% \mathrm{~b} / \mathrm{v}$, kontrol menggunakan aquadest dan pembanding Tetrasilkiln. Peperdisk diletakkan menggunakan pinset steril dengan jarak 2-3 cm dari pinggir cawan petri kemudian diinkubasi pada suhu $37^{\circ} \mathrm{C}$ selama 1 x 24 jam. Daerah hambatan yang terbentuk di ukur mengunakan jangka sorong. Perlakuan ini dilakukan sebanyak 3 kali dan diambil rataratanya. Semua data pengamatan dikumpulkan kemudian diolah dan dianalisis statistik. (Waluyo 2008)

\section{Hasil penelitian}

Tabel 1. Data hasil penelitian pengujian aktivitas antibakteri ekstrak Daun Jamblang ( Eugenia cumini merr.) terhadap pertumbuhan Streptococcus pyogenes

\begin{tabular}{|c|c|c|c|c|c|}
\hline \multirow{2}{*}{$\begin{array}{c}\text { Rep- } \\
\text { likasi }\end{array}$} & \multicolumn{5}{|c|}{ Zona hambatan ( mm) } \\
\cline { 2 - 6 } & $\mathrm{K}(-)$ & $2 \%$ & $4 \%$ & $8 \%$ & $\mathrm{~K}(+)$ \\
\hline I & 0 & 10,0 & 12,0 & 15,0 & 25,0 \\
\hline II & 0 & 10,0 & 12,0 & 15,0 & 26,0 \\
\hline III & 0 & 9,0 & 11,0 & 13,0 & 27,0 \\
\hline Jumlah & 0 & 29,0 & 35,0 & 43,0 & 78,0 \\
\hline $\begin{array}{c}\text { Rata } \\
\text {-rata }\end{array}$ & - & 9,67 & 11,67 & 14,33 & 26,00 \\
\hline
\end{tabular}

Berdasarkan tabel 1 diatas menunjukkan hasil pengukuran diameter zona hambatan setelah dilakukan inkubasi selama 1 x 24 jam pada suhu $37^{0} \mathrm{C}$ dalam lemari inkubator. Data tersebut memperlihatkan adanya aktivitas antibakteri dari masing-masing perlakuan, sedangkan pada kontrol negatif tidak memperlihatkan aktivitas antibakteri karena diameter diatas yaitu $9,67 \mathrm{~mm}$ merupakan diameter paperdisk yang digunakan pada penelitian ini, untuk kontrol positif memperlihatkan aktivitas antibakteri yang lebih besar yaitu rata-rata $26,0 \mathrm{~mm}$, dibandingkan dengan Ekstrak Jamblang $2 \%$ b/v, $4 \%$ b/v dan $8 \% \mathrm{~b} / \mathrm{v}$.

\section{Pembahasan}

Penyakit yang disebabkan oleh infeksi bakteri Streptococcus pyogenes bermula di tenggorokan dan kulit termasuk faringitis (radang tenngorokan) dan infeksi kulit setempat (Impetiga). Penyakit Erisipelas dan selulitis memiliki ciri oleh pertumbuhan dan penyebaran Streptococcus pyogenes di lapisan dalam kulit. 
Daun Jamblang (Eugenia cumini Merr.) merupakan Famili Myrtaceae, memiliki kandungan kimia yaitu asam malat, asam oksalat, asam galat, asam betulic, tannin, flavonoid dan minyak essensial. Daun jamblang berkhasiat sebagai obat diare, sariawan dan antibakteri pada beberapa infeksi faringitis (Radang tenggorokan) dan infeksi kulit setempat (Impetiga) Erisipelas dan selulitis pada lapisan kulit

Pada penelitian ini pengujian aktivitas antibakteri ekstrak Jamblang yang di peroleh dari Tamalanrea Kota Makassar terhadap bakteri Streptococcus pyogenens, dengan mengukur aktivitas antibakterinya dengan metode difusi agar atau diffusion ( test kibry dan bauer ). Sebelum dilakukan pengujian, terlebih dahulu bakteri diremajakan dari kultur bakteri murni, lalu di buat suspensi bakteri.

Pada metode disc diffusion, paper disk yang diletakkan pada medium Nutrient agar yang telah diinokulasi dengan Streptococcus pyogenes . Paper disk terlebih dahulu direndam ke dalam ekstrak jamblang dengan konsentrasi $2 \%$ b/v, 4 $\% \mathrm{~b} / \mathrm{v}, 8 \% \mathrm{~b} / \mathrm{v}$, dan kontrol dengan aqua steril serta pembanding menggunakan Tetrasiklin. Metode ini dilakukan untuk melihat besarnya diameter zona hambatan yeng terbentuk terhadap bakteri Streptococcus pyogenes setelah di inkubasi 1 x 24 jam. Ekstrak daun jamblang akan berdifusi keluar untuk menghambat pertumbuhan bakteri pada medium yang ditunjukkan dengan adanya daerah bening pada zona hambatan yang terbentuk pada medium disekeliling paper disk. Zona hambatan yang terbentuk kemudian di ukur menggunakan jangka sorong.

Berdasarkan hasil penelitian yang telah dilakukan menunjukkan rata - rata diameter zona hambatan pada pemberian ekstrak daun Jamblang dengan konsentrasi $2 \% \mathrm{~b} / \mathrm{v}$ sebesar $9,67 \mathrm{~mm}, 4 \% \mathrm{~b} / \mathrm{v}$ sebesar $11,67 \mathrm{~mm}, 8 \% \mathrm{~b} / \mathrm{v}$ sebesar 14,3 mm, kontrol positif sebesar 26,0 mm,dan kontrol negatif tidak mempunyai aktivitas aktibakteri. Dari hasil ini terlihat ekstrak daun jamblang konsentrsi $8 \%$ b/v mempunyai daya hambat yang paling besar diantara semua kelompok perlakuan $(p<0,05)$, tetapi aktivitasnya masih dibawah kontrol positif Tetrasiklin $(\mathrm{p}<0,05)$.

Adapun kandungan kimia menurut kajian M. Cowman (1999) dari daun jamblang yang berkhasiat sebagai antibakteri yaitu senyawa flavonoid yang merupakan golongan fenol. Senyawa golongan fenol dan fenolik derivatnya juga dapat menimbulkan denaturasi protein yang terdapat pada dinding sel, sehingga dapat merusak susunan dan merubah mekanisme permiabilis dari mikrosom, lisosom dan dinding sel, selain itu juga terdapat Tanin yang dapat menghambat pertumbuhan bakteri dengan cara mengkoagulasi bakteri. Tanin memiliki peran sebagai antibakteri dengan cara mengikat protein sehingga pembentukan dinding sel akan terhambat. Adapun mekanisme penghambatan tanin menurut kajian yang dilakukan oleh Gopinath, S. M., Dkk (2012) yaitu dengan cara melisis dinding bakteri sehingga dengan muda tanin dapat dengan masuk ke dalam sel bakteri dan mengkoagulasi protoplasma sel bakteri, salain itu Minyak atsiri yang terdapat dalam tanaman Jamblang juga berperan dengan cara menggangu proses terbentuknya membran atau dinding sel bakteri.

\section{Kesimpulan}

Berdasarkan hasil penelitian dan pembahasan, maka dapat disimpulkan Ekstrak Daun Jamblang pada konsentrasi $2 \%$ b/v, $4 \%$ b/v dan $8 \%$ b/v mempunyai aktivitas antibakteri terhadap pertumbuhan Streptococcus pyogenes namun aktivitas antibakteri masih dibawah Tetrasiklin $(\mathrm{p}<0,05)$.

\section{Saran}

Untuk mendapatkan efektivitas yang sebanding dengan Tetrasiklin dalam menghambat pertumbuhan bakteri Streptococcus pyogenes maka dosis ekstrak perlu ditingkatkan.

\section{DAFTAR PUSTAKA}

Arifin, Helmi, dkk . 2006. Standarisasi Ekstrak Etanol Daun Eugenia cumini Merr. J. Sains Tek. Farmasi.

Departemen Kesehatan Republik Indonesia, 1986. Sediaan Galenik, Direktorat Jenderal Pengawasan Obat dan Makanan, Jakarta.

Departemen Kesehatan Republik Indonesia, 1995. Farmakope Indonesia, Edisi IV, Direktorat Jenderal Pengawasan Obat dan Makanan, Jakarta.

Gopinath, S. M., C. K. Rakesh, G. M. Ashwini Patil and K. S. Dayananda. 2012. Preeliminary Phytochemical Evaluation of Leaf Extracts of Euphorbia hirta, Syzygium cumini of Siddarabetta Tumkur, District, Karnataka. International Journal of Pharma and Biosciences. 3(2):431-4

Mahmoud I, Marzouk M, Moharram M, El-Gindi M, Hassan A. 2001. Acylated Flavonol Glycosides from Eugenia jambolana Leaves. Phytochemistry 58. 1239-1244. 
M. M. Cowan. 1999. Plant Products as Antimicrobial Agents. Clin. Microbiol. Rev.12 (4): 564-582.

Pratiwi.S, 2010. Mikrobiologi Farmasi, PT Erlangga, Jakarta.

Ryan KJ; 2004. Sherris Medical Microbiology (edisi ke-4th ed.). McGraw Hill.USA

Sartono, R, 2011. Perawatan Tubuh dan Pengobatan-pengobatan Tradisional. Effhar dan Dahara Prize, Semarang
Sriningsih. 2008. Analisa Senyawa Golongan Flavonoid Herba Tempuyung (SonchusarvensisL): www.indomedia.com/intisari/1999/juni/te mpuyung.htm.(diakses tanggal 5 Januari 2018 )

Waluyo L., 2008. Teknik dan Metode Dasar Dalam Mikrobiologi. Universitas Muhammadiah Malang. Malang.

(c) (1) () () 